Article

\title{
Mineral Composition of Three Popular Wild Mushrooms from Poland
}

\author{
Michalina Gałgowska ${ }^{1}$ and Renata Pietrzak-Fiećko ${ }^{2, *(\mathbb{D}}$ \\ 1 Department of Meat Technology and Chemistry, Faculty of Food Sciences, University of Warmia and Mazury \\ in Olsztyn, Cieszyński 1 Sq, 10719 Olsztyn, Poland; michalina.galgowska@uwm.edu.pl \\ 2 Department of Commodities and Food Analysis, Faculty of Food Sciences, University of Warmia and \\ Mazury in Olsztyn, Cieszyński 1 Sq, 10-726 Olsztyn, Poland \\ * Correspondence: renap@uwm.edu.pl
}

Academic Editor: Ana Barros

Received: 8 July 2020; Accepted: 4 August 2020; Published: 6 August 2020

check for updates

\begin{abstract}
The region of Warmia and Mazury is characterized by the special diversity and richness of its natural environment, including large forest complexes, where wild mushrooms are commonly collected and consumed. This study aimed to examine the differences in mineral content (calcium, magnesium, sodium, potassium, iron, zinc, copper, manganese) of three species of mushrooms collected in north-eastern Poland. The research material consisted of dried samples of king bolete (Boletus edulis), bay bolete (Boletus badius), and chanterelle (Cantharellus cibarius) collected in the region of Warmia and Mazury. The content of the above-mentioned elements in mushroom fruit bodies was determined using the flame atomic absorption spectrometry (acetylene-air flame) and the emission technique (acetylene-air flame) for sodium and potassium. For the majority of microand macroelements, the studies confirmed the presence of significant differences in their content, depending on the species of fungi. The studied mushrooms cover a significant percentage of daily demand for many of the minerals. This concerns mainly copper, zinc, and potassium, although none of the species was a good source of calcium and sodium. Among the analyzed mushrooms, chanterelle is the best source of most minerals.
\end{abstract}

Keywords: edible mushrooms; Boletus edulis; Boletus badius; Cantharellus cibarius; minerals; microelements; macroelements

\section{Introduction}

The province of Warmia and Mazury is one of the least degraded areas in Poland, taking into account the natural environment. The whole province is located within the so-called "green lungs", which covers the cleanest regions of the country. Forests are the natural wealth of the Warmia and Mazury region. The properties of woods (appropriate substrate, age of stands) favor the occurrence of undergrowth, e.g., mushrooms. According to the data from the Statistical Yearbook of Forestry, in 2018, the purchase of mushrooms amounted to 122 tons, which ranked the region 6th place in the country in terms of the amount of fungal raw material obtained [1,2]. The most valued mushrooms include Boletus edulis, Boletus badius, and Cantharellus cibarius.

Boletus edulis (King Bolete) is considered one of the most appreciated species of wild edible mushrooms and is a popular food throughout the world [3,4]. It is very popular mainly because of its aroma, texture, and the presence of nutrients as well as biologically active compounds, which determine its nutritional and medicinal properties [5-7]. The fruiting bodies of the bay boletus (Boletus badius) are tasty, which makes them widely used in gastronomy. Furthermore, they contain many valuable substances, such as antioxidants (anisole, BHT toluene, tocopherol) and rare metals (manganese, zinc, selenium). Chanterelles (Cantharellus cibarius) are a desirable trade item because of their attractive taste, 
durability during transport and storage, and the fact that the sporocarps are rarely affected by insect larvae. In addition, this mushroom is rich in natural vitamin $C$ and contains high levels of potassium and vitamin $\mathrm{D}[8]$.

Wild mushrooms are commonly collected and consumed in Asia, Mexico, and Central-Eastern Europe. They are treated as an important food product, which is valued for its taste, nutritional value, and biological activity (antitumor, anticancer, anti-atherosclerosis and thrombosis inhibition, anti-inflammatory, hepatoprotective, and antihypertensive) [9-16]. Mushrooms are a good source of minerals, vitamins, potassium, dietary fiber, water, carbohydrates, and are low in lipids and sodium [17-20]. They are known to uptake and accumulate different chemical compounds [21-25], nevertheless the efficiency of this process may depend on various factors $[19,26]$.

Currently, knowledge of the mineral content in edible mushrooms is relatively extensive. In many countries (South Africa, Turkey, Greece, Serbia, China, and others), numerous studies have been conducted on the mineral composition of various species of fungi to more accurately estimate their nutritional and health value and the mechanism of accumulation of individual components [22,27-32]. In Poland, large-scale analyses have been conducted, among others, by Falandysz, whose numerous reports concern a wide spectrum of elements determined in many species of mushrooms collected in various sites in Poland and around the world [33-36]. Siwulski, Mleczek, and Rzymski have also carried out numerous studies on cultivated and wild mushrooms from non-contaminated and contaminated areas [26,37-41].

Mushrooms owe their ability to accumulate micro- and macroelements to the specific structure of mycelium: the exposed surface of vegetative cells and large hyphae surfaces [42]. They are able to store minerals in large quantities even exceeding concentrations found in the medium in which they have grown $[43,44]$. The uptake of elements considered physiologically essential to mushrooms (K, P, $\mathrm{Mg}, \mathrm{Mn}, \mathrm{Cu}, \mathrm{Ca}, \mathrm{Na}, \mathrm{Zn}$ ) by mycelia and their deposition in fruiting bodies is species dependent [45]. Therefore, unlike vascular plants, mushrooms are able to accumulate high concentrations of minerals, even when growing in soils with low metal contents [35]. In this way, they become a particular rich source of minerals. In Kalač's opinion, the levels of elements in wild mushrooms significantly increase with the increasing age of mycelium and extended time between the fructifications [46]. Variability in the chemical composition of mushrooms within a species is greater than that of plants. Since each individual fruit body can result from the crossbreeding of different hyphae and so presents a distinct genotype, the mineral contents in a mushroom species vary widely. Except for the species, the essential factors affecting trace element level in fruit bodies are the level of substrate composition, soil, $\mathrm{pH}$, enzyme activity, and local pollution with trace elements.

With this background, the aim of the study was to determine the accumulation level of minerals of three species of mushrooms collected from the Warmia and Mazury region as well as to evaluate mushroom contribution to the daily intake of the studied bioelements.

\section{Material and Methods}

The research material consisted of dried samples of king bolete (Boletus edulis) and bay bolete (Boletus badius), which were purchased from July to November from a company in the region of Warmia and Mazury. In the same period, samples of fresh chanterelles (Cantharellus cibarius) were obtained from mushroom selling stands, located in the province of Warmia and Mazury (Figure 1). Chanterelles were selected, cleaned (removal of impurities in the form of needles, pebbles, tree elements), and dried in a special drier according to PN-68/A-78508 [47] under laboratory conditions at $60{ }^{\circ} \mathrm{C}$ to obtain a constant weight. In total, 20 samples of each species of mushroom were collected (2 samples of each species per month), where each was divided into three-unit samples. The results in the table are presented as mean values of all samples (in total $n=60$ per each species). In addition, each series of mineralized samples included a parallel reagent test. 


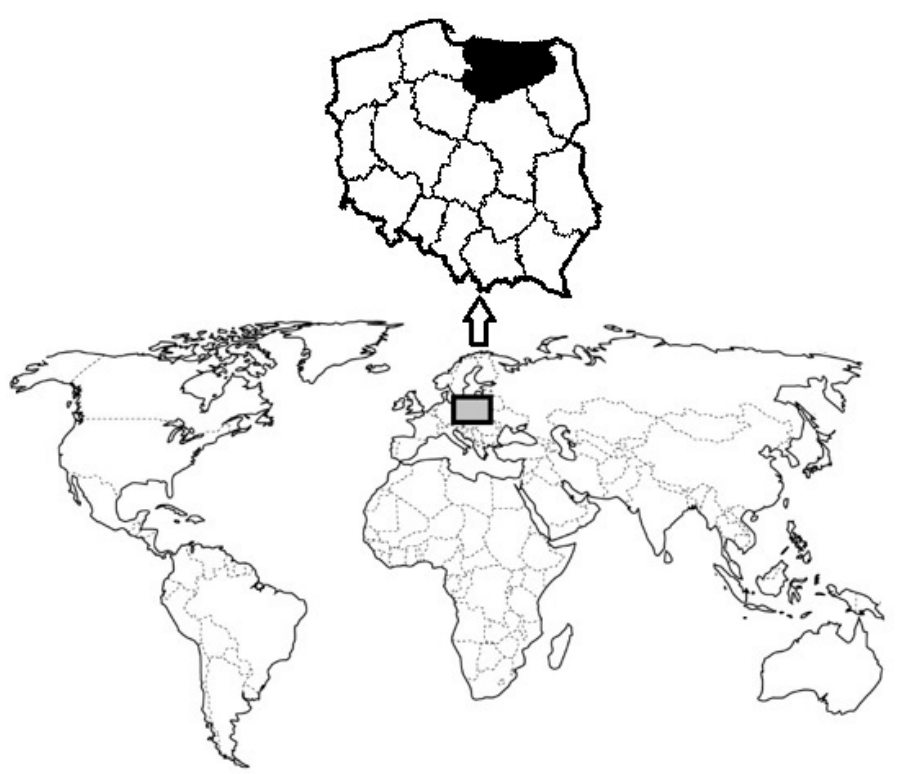

Figure 1. Localization of sampling of research mushroom species -Warmia and Mazury region of Poland.

\subsection{Samples Preparation}

Prepared unit samples of mushrooms were ground to a powder and weighed into glass tubes in an amount of about $1 \mathrm{~g}$. The remainder was stored in closed polyethylene bags at $18^{\circ} \mathrm{C}$.

\subsection{Samples Mineralization}

Mineralization of samples was carried out according to the method described by Whiteside \& Miner (1984) [48]. The weighed samples were mineralized using the "wet" method in a mixture of nitric and perchloric acids (3:1). The analysis was performed in an aluminum electric heating block with temperature programming (VELP DK 20-VELP Scientifica, Usmate, Italy), within 5-6 h, gradually increasing the temperature from $120{ }^{\circ} \mathrm{C}$ to $200{ }^{\circ} \mathrm{C}$. The obtained colorless mineralizate was quantitatively transferred into $50 \mathrm{~cm}^{3}$ volumetric flasks and filled up to the mark with deionized water. Reagent samples were prepared along with the samples.

\subsubsection{Determination of Copper, Manganese, Iron, Zinc, Calcium and Magnesium}

In previously prepared mineralizates, the contents of copper $(\mathrm{Cu})$, manganese $(\mathrm{Mn})$, iron $(\mathrm{Fe})$, zinc $(\mathrm{Zn})$, calcium $(\mathrm{Ca})$, and magnesium $(\mathrm{Mg})$ were determined by flame atomic absorption spectrometry (acetylene-air flame). The analyses were performed using an atomic absorption spectrometer-iCE 3000 SERIES-THERMO (Thermo-Scientific, Hemel Hempstead, Hertfordshire, UK), equipped with a GLITE data station, background correction (deuterium lamp) and appropriate cathode lamps. For the calcium determination, a 10\% aqueous solution of lanthanum chloride was added to all measured solutions in a quantity ensuring a final $\mathrm{La}^{+3}$ concentration of $1 \%$. The determination was carried out at wavelengths (in $\mathrm{nm}$ ) for individual minerals: 324.8 copper; 279.5 manganese; 248.3 iron; 213.9 zinc; 285.2 magnesium; 422.7 calcium.

\subsubsection{Determination of Sodium and Potassium}

The sodium and potassium contents ( $\mathrm{Na}$ and $\mathrm{K}$ ) were determined by the emission technique (acetylene-air flame). The analyzes were performed using the atomic absorption spectrometer iCE 3000 SERIES-THERMO (Thermo-Scientific, Hemel Hempstead, Hertfordshire, UK), equipped with a GLITE data station, operating in an emission system. The determination was carried out at wavelengths (in $\mathrm{nm}$ ) for individual elements: 589.0 sodium; 766.5 potassium. 
The selected concentrations of the standard solutions of individual micro- and macronutrients formed the measuring range of the analytical method used in the experiment. To determine the equation of the relationship between the measure of the signal generated by the device and the content of the analyte in the sample, calibration curves for individual elements were prepared. For this purpose, three parallel absorbance measurements were made for each standard solution, starting with measurements for the blank. Calibration curves for copper, manganese, iron, zinc, magnesium, calcium, sodium, potassium, cadmium, and lead were created based on the average absorbance values. The equations of the straight lines describing the curves were determined by the method of least squares (linear regression) according to the formula:

$$
y=a x+b
$$

where a denotes slope coefficient (directional) of the straight line and $b$ the straight line shift coefficient.

Linearity, i.e., the range of the content of the analyte, for which the output signal of the measuring device is proportional to this content, was determined based on the regression coefficient $\left(\mathrm{R}^{2}\right)$. The value of this parameter should meet the condition $R^{2} \geq 0.999$.

The accuracy of the method was checked based on an examination of the certified reference material INCT-TL-1 tea leaves, which were analyzed five times.

\subsection{Statistical Methods}

The obtained results of the content of macro- and micromineral elements in mushrooms were subjected to statistical analysis. The computer package Statistica 13.1 (StatSoft Inc., Tulsa, OK, USA) was used for calculations and MS Excel was used to present the results.

First, the measures of descriptive statistics were calculated, such as arithmetic mean, median, variance, standard deviation, and range, to characterize the distribution of values of the examined features. Then, the Kolmogorov-Smirnov test was performed to check the compliance of the distribution of the examined feature with the normal distribution and the median series test to check if the values have a random distribution.

Non-parametric tests were used to compare the average levels of feature values between samples due to a small number of samples, no normal distribution for most samples, or no random distribution of most samples.

To study the differences between the two independent groups, the U-Mann-Whitney test was used, which is equivalent to the parametric t-test for independent samples. This verifies the null hypothesis regarding "equality of means in two independent samples" against the alternative hypothesis saying that these means are not equal. When comparing average levels in several independent samples, the Kruskal-Wallis test was used to verify the null hypothesis assuming "equality of means in the tested samples" against the alternative hypothesis saying that these means are not equal. Using both tests, the significance level was $p=0.05$. Fungi species were the assumed grouping factor. The results of the experiment and their statistical interpretation are presented in Table 1.

Table 1. Mean content of minerals in the studied mushrooms $(\bar{x} \pm \mathrm{SD}),(n=60)[\mathrm{mg} / \mathrm{kg}$ d.w.].

\begin{tabular}{|c|c|c|c|c|c|c|c|c|}
\hline Species & $\mathrm{Cu}$ & $\mathrm{Fe}$ & Mn & $\mathrm{Zn}$ & $\mathrm{Ca}$ & $\mathrm{K}$ & $\mathrm{Mg}$ & $\mathrm{Na}$ \\
\hline & \multicolumn{4}{|c|}{ Microelements } & \multicolumn{4}{|c|}{ Macroelements } \\
\hline Boletus badius & $29.7 \pm 4.22 b$ & $38.8 \pm 3.44 \mathrm{c}$ & $11.9 \pm 2.54 \mathrm{~b}$ & $163 \pm 7.70 \mathrm{a}$ & $54.7 \pm 7.03 \mathrm{~b}$ & $36,001 \pm 2278 b$ & $526 \pm 49.6 \mathrm{~b}$ & $568 \pm 67.3 b$ \\
\hline Boletus edulis & $23.4 \pm 6.60 \mathrm{c}$ & $48.9 \pm 4.00 \mathrm{~b}$ & $11.3 \pm 2.35 b$ & $158 \pm 24.1 \mathrm{~b}$ & $75.3 \pm 3.00 \mathrm{~b}$ & $29,136 \pm 1776 c$ & $566 \pm 48.0 \mathrm{~b}$ & $653 \pm 61.3 \mathrm{a}$ \\
\hline Cantharellus cibarius & $48.4 \pm 4.20 \mathrm{a}$ & $58.9 \pm 5.28 \mathrm{a}$ & $23.7 \pm 3.25 \mathrm{a}$ & $113 \pm 9.50 c$ & $211 \pm 73.2 \mathrm{a}$ & $46,024 \pm 4492 \mathrm{a}$ & $842 \pm 54.2 \mathrm{a}$ & $142 \pm 19.2 c$ \\
\hline
\end{tabular}

Explanation: values marked with the same letters do not differ significantly at significance level $p<0.05 ; \bar{x}-$ mean values, SD—standard deviation.

\section{Results}

The mean content of minerals in the studied species of mushrooms is presented in Table 1 . The Cu content in the three species of mushrooms is varied. The highest amount of $\mathrm{Cu}$ at $48.4 \mathrm{mg} / \mathrm{kg} \mathrm{d}$.w. 
was observed in C. cibarius. Much lower levels were determined for B. edulis (23.41 mg/kg d.w.) and B. badius (29.7 mg/kg d.w.). Fe content turned out to be varied between species. The highest Fe content was determined for C. cibarius (58.9 mg/kg d.w.), followed by B. edulis ( $48.9 \mathrm{mg} / \mathrm{kg} \mathrm{d.w.).} \mathrm{The} \mathrm{lowest}$ content of this element was observed in the B. badius $(38.8 \mathrm{mg} / \mathrm{kg} \mathrm{d.w.).} \mathrm{The} \mathrm{content} \mathrm{of} \mathrm{Mn}$ in C. cibarius fruit bodies (23.7 mg/kg d.w.) was significantly higher than in B. edulis and B. badius (11.3 and $11.9 \mathrm{mg} / \mathrm{kg}$ d.w., respectively). In general, B. edulis, B. badius, and C. cibarius differed significantly in terms of $\mathrm{Zn}$ content.

The highest Ca content, almost three times higher than in B. edulis $(75.3 \mathrm{mg} / \mathrm{kg}$ d.w.) and almost four-fold than in in B. badius (54.7 mg/kg d.w.), was determined in C. cibarius and equaled $211 \mathrm{mg} / \mathrm{kg}$ d.w. The highest content of this element was determined in B. badius (163 $\mathrm{mg} / \mathrm{kg} \mathrm{d.w.),} \mathrm{and} \mathrm{the} \mathrm{lowest}$ was in C. cibarius (112.7 mg/kg d.w.), while B. edulis contained $158 \mathrm{mg} / \mathrm{kg}$ d.w. of Zn. Significant differences in $\mathrm{K}$ content were found between all the analyzed fungi. The highest content of this element was determined for C. cibarius $(46,024 \mathrm{mg} / \mathrm{kg} \mathrm{d.w.)}$, followed by B. badius $(36,001 \mathrm{mg} / \mathrm{kg} \mathrm{d.w.)}$ and B. edulis $(29,136 \mathrm{mg} / \mathrm{kg} \mathrm{d.w.).} \mathrm{The} \mathrm{Mg} \mathrm{contents} \mathrm{for} \mathrm{B.} \mathrm{edulis} \mathrm{and} \mathrm{B.} \mathrm{badius} \mathrm{were} 566$ and $526 \mathrm{mg} / \mathrm{kg}$ d.w., respectively. The content of $\mathrm{Mg}$ in C. cibarius was significantly higher than in the other mushrooms (842 mg/kg d.w.). The sodium contents appear to be varied, where more than four times lower contents than in other species $(142 \mathrm{mg} / \mathrm{kg}$ d.w.) were determined in C. cibarius. Significant differences between the results determined for B. edulis (653 mg/kg d.w.) and B. badius (568 mg/kg d.w.) were also indicated.

Table 2 shows the calculated coverage of the daily demand for selected micro- and macroelements in the case of the consumption of $25 \mathrm{~g}$ of dried mushrooms, which can be equivalent to $250 \mathrm{~g}$ of fresh mushrooms. In relation to the recommended daily allowance (RDA) of $\mathrm{Cu}$, the studied mushrooms can be a rich source of this element in the human diet. Daily demand is met to the highest degree after consumption of C. cibarius. It covers as much as $134-173 \%$ of the demand in children and adolescents and $173 \%$ in adults. The lowest percentage of daily demand for $\mathrm{Cu}$ is covered by B. edulis - children and adolescents: $65.0-83.6 \%$ and adults: $83.6 \%$. The coverage of the daily requirement after consumption of $B$. badius by children and adolescents is $82.6-106 \%$ and by adults: $106 \%$. The largest percentage of the demand for Fe in children, adolescents and adults is covered by C. cibarius $(9.83-14.8 \%, 8.19-14.8 \%$, respectively). B. badius covers the daily requirements to the lowest degree-among children and adolescents: $6.47-9.70 \%$ and adults: $5.39-9.70 \%$. Values obtained for B. edulis are 8.15-12.2\% and 6.79-12.2\%, respectively. The highest daily demand for Mn is covered by C. cibarius: $43.3-63.5 \%$ in children and adolescents and $41.4-52.9 \%$ in adults. Comparable values were determined for B. edulis and B. badius: $12.9-18.9 \%$ (children and adolescents), $12.3-15.7 \%$ (adults), 13.6-19.9\% (children and adolescents), 12.9-16.6\% (adults), respectively. In the case of daily demand for $\mathrm{Zn}$, the highest values were obtained for B. badius: children and adolescents and adults: $37.1-51.1 \%$. Comparable amounts of recommended $\mathrm{Zn}$ consumption were obtained for B. edulis: 35.8-49.2\%, while for C. cibarius it was 25.6-35.2\%. Coverage of the daily Ca demand by consuming studied mushrooms is negligible. In the case of $B$. badius it is the lowest, $0.11 \%$ among children and adolescents and $0.11-0.14 \%$ in adults. B. edulis covers the recommended intake in $0.16-0.19 \%$ (adults) and 0.15 in children. Higher values were obtained for C. cibarius, namely $0.40 \%$ for children and adolescents, while for adults it was $0.44-0.53 \%$. The studied mushrooms are characterized by a high $\mathrm{K}$ content. By consuming C. cibarius, the adequate intake is met in 32.9-47.9\% among children and adolescents and in $32.9 \%$ in adults. The lowest degree of coverage was provided by B. edulis (children and adolescents: 20.8-30.4\%; adults: 20.8\%), while for B. badius, 25.7-37.5\% coverage (children and adolescents) and $25.7 \%$ coverage (adults) was obtained. The demand for $\mathrm{Mg}$ can be realized the most after consuming C. cibarius. The values obtained for children and adolescents were: $5.13-8.77 \%$ and for adults: $5.01-6.79 \%$. Recommended daily intake of $\mathrm{Mg}$, in the case of $B$. edulis was 3.45-5.89\% (children and adolescents) and 3.37-4.56\% (adults). The values obtained for the B. badius were 3.21-5.48\% and 3.13-4.24\%, respectively. The demand for Na does not exceed $1.10 \%$ for the consumption of each of the studied species of fungi. The highest value was obtained for B. edulis: 1.09-1.26, then for B. badius: $0.95-1.09 \%$. Daily adequate intake (AI) of $\mathrm{Na}$ is realized in the case of $\mathrm{C}$. cibarius only in $0.24-0.27 \%$. 
Table 2. Coverage of the daily demand for minerals after eating $25 \mathrm{~g}$ of dried mushrooms.



Source: own study based on Jarosz et al. 2017 [49]. Explanation: RDA—Recommended Daily Allowance [mg/person]; AI—Adequate Intake [mg/person]; DDC—Daily demand coverage.

\section{Discussion}

Brzezicha-Cirocka et al. (2016) [34] obtained similar results from research on the C. cibarius from Morag (Warmia and Mazury region), where the $\mathrm{Cu}$ content was determined at $54 \mathrm{mg} / \mathrm{kg}$ d.w. (33-77 mg/kg d.w.). Falandysz et al. (2017) [36] also recorded a Cu content of $41 \mathrm{mg} / \mathrm{kg}$ d.w. (34-53 mg/kg d.w.) in C. cibarius from Poland, however in these mushrooms from China, it was $31 \mathrm{mg} / \mathrm{kg}$ d.w. Smaller amounts of Cu-31.2 mg/kg d.w. were detected by Yildiz et al. (2019) [28] in mushrooms from Turkey, while higher contents were determined by Kolundžić et al. (2017) [29] in C. cibarius from Serbia: $60 \mathrm{mg} / \mathrm{kg}$ d.w. Mleczek et al. (2016) [50] observed $18.7 \mathrm{mg} / \mathrm{kg}$ d.w. Cu in mushroom species growing near heavily trafficked road in Poland. Cu content in the B. badius ranging from $9.70-13.6 \mathrm{mg} / \mathrm{kg}$ d.w. was observed by Mleczek et al. (2013) [37], who were examining fungi from five regions of Poland. Mleczek et al. (2016) [43] analyzed species obtained from unpolluted areas of acidic sandy soils located in the Wielkopolska region and from areas where alkaline flotation tailings from copper production had been stored. They received results ranging from $14-17 \mathrm{mg} / \mathrm{kg}$ d.w. and 9-13 mg/kg d.w., respectively. These values differ from those obtained in the current study. Karmańska \& Wẹdzisz (2010) [42] determined the average Cu content in the B. badius from the province of Łódź at $29.2-34.1 \mathrm{mg} / \mathrm{kg}$ d.w. while Kuziemska et al. (2019) [51] found $34.8 \mathrm{mg} / \mathrm{kg}$ d.w in Masovian Voivodeship, and Adamiak et al. (2013) [51] reported $23.4 \mathrm{mg} / \mathrm{kg}$ d.w. in this species from Wysoczyzna Siedlecka region. Karmańska \& Wẹdzisz (2010) [42] obtained similar contents of $\mathrm{Cu}$ in B. edulis: $22.0-22.9 \mathrm{mg} / \mathrm{kg}$ d.w. Also, Brzezicha-Cirocka et al. (2016) [34] reported 15-70 and 6-72 mg/kg d.w. in B. edulis obtained in Morag and on the Tarnobrzeska Plain, respectively. Liu et al. (2016) [30] determined 19-73 mg/kg d.w. of $\mathrm{Cu}$ in B. edulis from China. In this species analyzed in Africa, Rasalanavhoa et al. (2020) [27] determined 39.7-101 mg/kg d.w. of Cu. Adamiak et al. (2013) [52] obtained values of 30.6-31.8 mg/kg d.w. while examining mushrooms from the Wysoczyzna Siedlecka region (Tables 3 and 4). 
Table 3. Minerals in Boletus edulis (adapted) [mg/kg d.w.].

\begin{tabular}{|c|c|c|c|c|c|c|c|c|c|c|}
\hline & $\mathrm{Cu}$ & $\mathrm{Fe}$ & Mn & $\mathrm{Zn}$ & $\mathrm{Ca}$ & $\mathbf{K}$ & $\mathrm{Mg}$ & $\mathrm{Na}$ & \multirow{2}{*}{ Loc. } & \multirow{2}{*}{ Ref. } \\
\hline & \multicolumn{4}{|c|}{ Microelements } & \multicolumn{4}{|c|}{ Macroelements } & & \\
\hline Mean & nd & nd & nd & nd & nd & nd & nd & nd & \multirow{2}{*}{$\begin{array}{l}\text { Southwest } \\
\text { China }\end{array}$} & \multirow{2}{*}{ [30] } \\
\hline Range & $19-73$ & $221-358$ & $28-69$ & $76-88$ & $384-863$ & $15,744-25,486$ & $574-708$ & $617-1184$ & & \\
\hline Mean & 37 & 200 & 21 & 160 & 480 & 27,000 & 910 & 360 & Morag, & \multirow{2}{*}{ [34] } \\
\hline Range & $15-70$ & $51-610$ & $9-47$ & $71-220$ & $160-900$ & $21,000-31,000$ & $680-1300$ & $57-1400$ & Poland & \\
\hline Mean & 36 & 47 & 8,6 & 210 & 200 & 32,000 & 850 & 190 & Tarnobrzeska & \multirow{2}{*}{ [34] } \\
\hline Range & $6-72$ & $25-210$ & $4-15$ & $130-320$ & $110-300$ & $24,000-41,000$ & $680-1000$ & $18-560$ & Plain, Poland & \\
\hline Mean & nd & nd & nd & nd & nd & nd & nd & nd & \multirow{2}{*}{$\begin{array}{l}\text { KwaZulu-Natal, } \\
\text { South Africa }\end{array}$} & \multirow{2}{*}{ [27] } \\
\hline Range & 39.7-101 & $20-130$ & $3.53-22.7$ & $53.6-107$ & $26.5-206$ & $18,180-27,090$ & $540-860$ & $300-1050$ & & \\
\hline Mean & nd & nd & nd & nd & nd & nd & nd & nd & \multirow{2}{*}{$\begin{array}{c}\text { The province } \\
\text { of Łódź, } \\
\text { Poland }\end{array}$} & \multirow{2}{*}{ [42] } \\
\hline Range & $22.0-22.9$ & $65.3-91.2$ & $15.5-19.2$ & $44.6-50.3$ & $155-158$ & nd & $306-325$ & nd & & \\
\hline Mean & 30.9 & nd & nd & 137 & nd & nd & nd & nd & \multirow{2}{*}{$\begin{array}{l}\text { Wysoczyzna } \\
\text { Siedlecka, } \\
\text { Poland }\end{array}$} & \multirow[b]{2}{*}{ [52] } \\
\hline Range & $30-31.8$ & nd & nd & $131-140$ & nd & nd & nd & nd & & \\
\hline
\end{tabular}

Explanation: Loc.-lokalization; Ref.-references; nd-no data.

Table 4. Minerals in Boletus badius (adapted) [mg/kg d.w.].

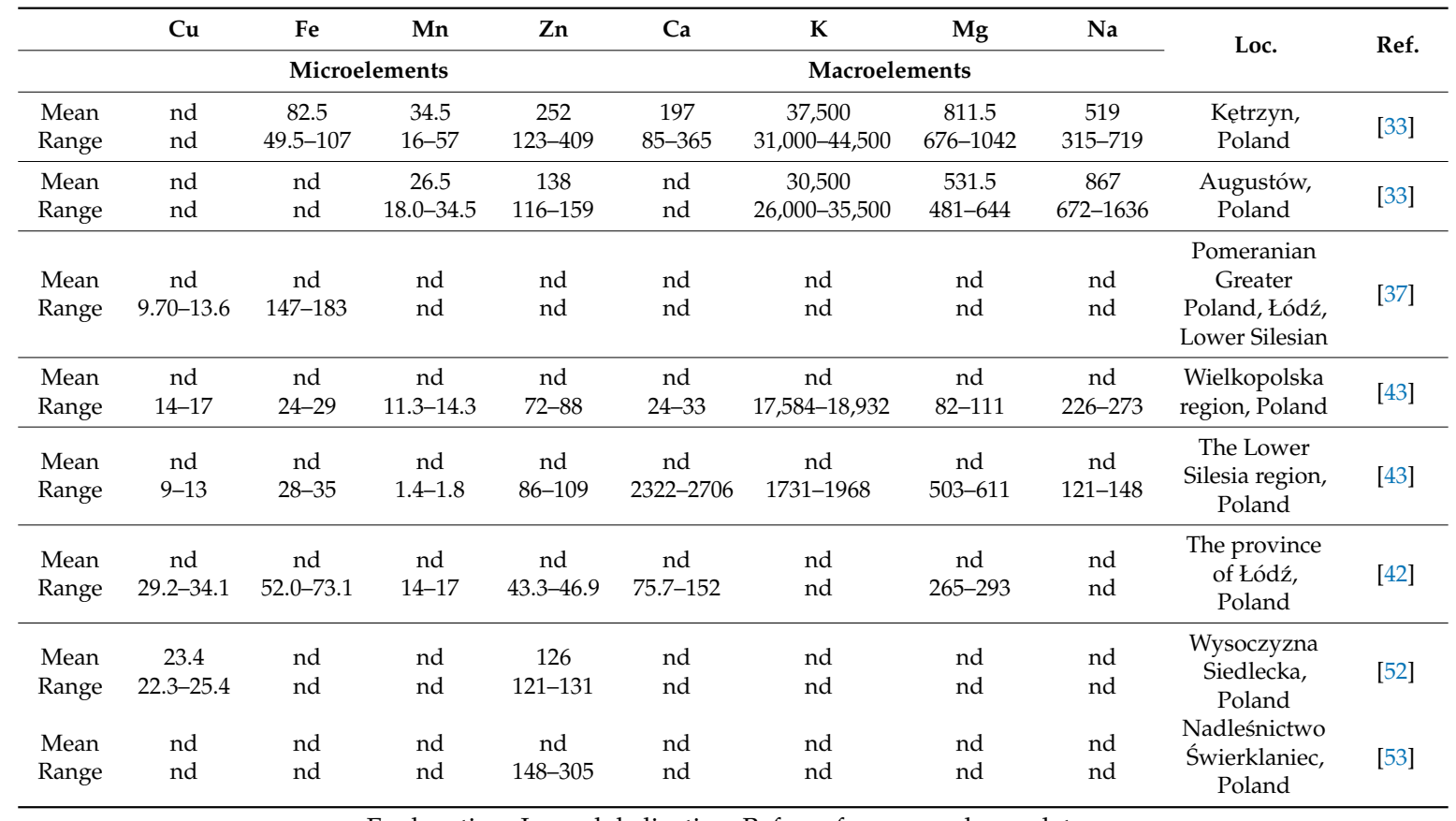

Explanation: Loc.-lokalization; Ref.-references; nd-no data.

Comparable manganese contents in C. cibarius were obtained by Ayaz, et al. (2011) [54] $25.2 \mathrm{mg} / \mathrm{kg}$ d.w. Brzezicha-Cirocka et al. (2016) [34] determined $30 \mathrm{mg} / \mathrm{kg}$ d.w. (20-63 mg/kg d.w.) of this mineral, while Falandysz et al. (2017) [36] detected $38 \mathrm{mg} / \mathrm{kg}$ d.w. in C. cibarius from Poland and $19 \mathrm{mg} / \mathrm{kg}$ d.w. in this species from China. Yildiz et al. (2019) [28] determined only $4.6 \mathrm{mg} / \mathrm{kg}$ of $\mathrm{Mn}$ in C. cibarius from Turkey, while Kolundžić et al. (2017) [29] reported up to $41 \mathrm{mg} / \mathrm{kg}$ d.w. in this mushroom from Serbia (Table 5). Similar contents of $\mathrm{Mn}$ in B. badius from unpolluted areas of the Wielkopolska region, ranging from 11.3 to $14.3 \mathrm{mg} / \mathrm{kg}$ d.w. were noted by Mleczek et al. (2016) [43], as well as Karmańska \& Wędzisz (2010) [42] who found 14-17 mg/kg d.w. Kojta \& Falandysz (2016) [33] determined $34.5 \mathrm{mg} / \mathrm{kg}$ d.w. in B. badius collected from Kętrzyn and $26.5 \mathrm{mg} / \mathrm{kg}$ d.w. in this species from Augustów: Low Mn contents were determined by Mleczek et al. (2016) [43], who were examining B. badius samples from areas where alkaline flotation tailings from $\mathrm{Cu}$ production were stored: $1.4-1.8 \mathrm{mg} / \mathrm{kg}$ d.w. In the case of B. edulis, Brzezicha-Cirocka et al. (2016) [34] obtained results of Mn content within 9-47 mg/kg d.w. for mushrooms from Morag and $4-15 \mathrm{mg} / \mathrm{kg}$ d.w. for this species from Tarnobrzeska Plain, where the steel 
mill Huta Stalowa Wola is located. Karmańska \& Wędzisz (2010) [42] reported 15.5-19.2 mg/kg d.w. in B. badius from the province of Łódź. Rasalanavhoa et al. (2020) [27] determined 3.53-22.69 mg/kg d.w. of Mn in B. edulis from Africa, while Liu et al. (2016) [30] obtained values of 28-68 mg/kg d.w. in material originating from China. Karmańska \& Wędzisz (2010) [42] determined the value ranging from 15.5-19.2 mg/kg d.w., while Ouzouni et al. (2007) [17] and Ayaz et al. (2011) [54] reported the value ranges of 100 to $180 \mathrm{mg} / \mathrm{kg}$ d.w.

Table 5. Minerals in Cantharellus cibarius (adapted) [mg/kg d.w.].

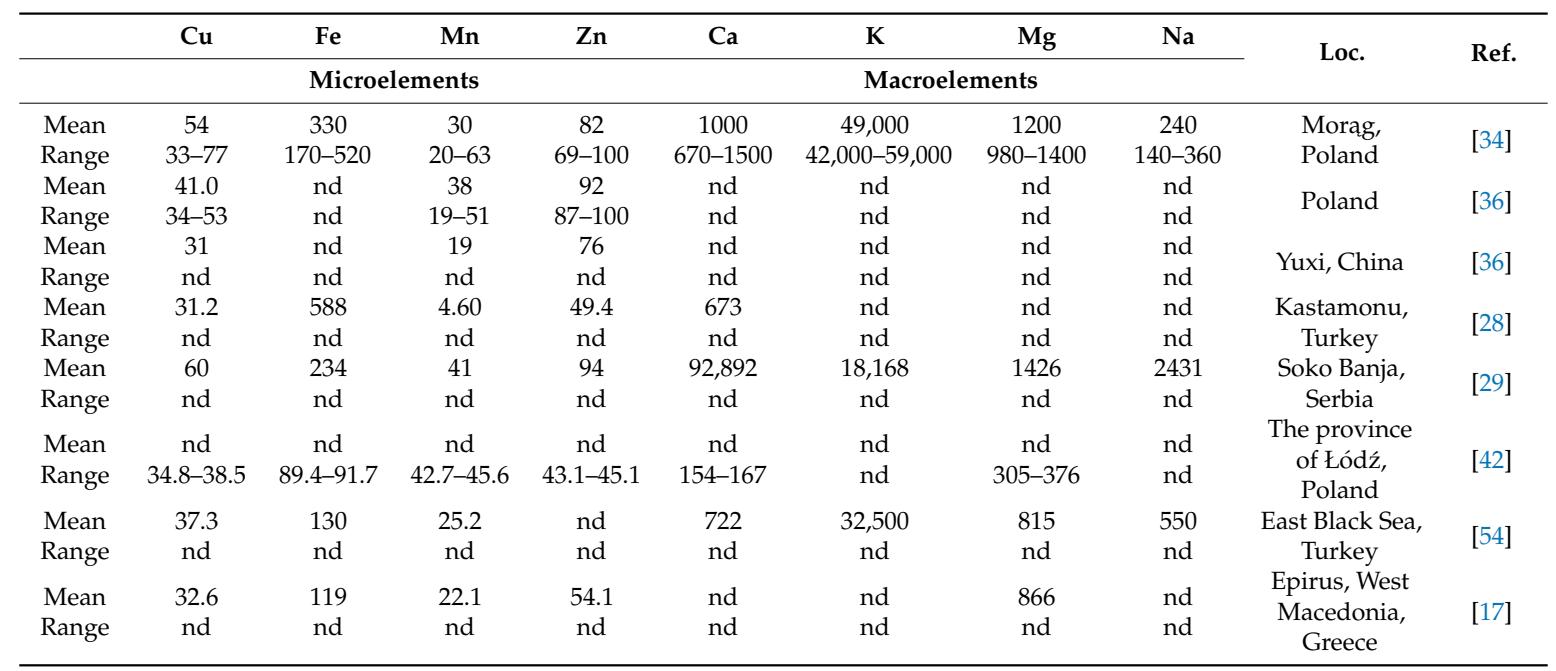

Explanation: Loc.-lokalization; Ref.-references; nd-no data.

Brzezicha-Cirocka et al. (2016) [34] determined Fe at the level of 170-520 mg/kg d.w. in C. cibarius from Morag. In this species analyzed in Turkey and Serbia, 588.5 and $234 \mathrm{mg} / \mathrm{kg} \mathrm{d.w.,} \mathrm{respectively,}$ were recorded [28,29]. Mleczek et al. (2016) [43] determined a lower Fe content in the B. badius in Wielkopolska region: $24-29 \mathrm{mg} / \mathrm{kg}$ d.w. and $28-35 \mathrm{mg} / \mathrm{kg}$ d.w. from a polluted area of the province of Lower Silesia. Kojta \& Falandysz (2016) [33] determined the amount of this mineral at $82.5 \mathrm{mg} / \mathrm{kg}$ d.w. in the mushrooms from Ketrzyn. Mleczek et al. (2013) [37] found significantly higher contents of Fe in B. badius analyzing samples from five Polish provinces: $147-183 \mathrm{mg} / \mathrm{kg} \mathrm{d}$.w. Brzezicha-Cirocka et al. (2016) [34] received similar Fe content in B. edulis: $25-210 \mathrm{mg} / \mathrm{kg}$ d.w. for mushrooms from the Tarnobrzeg Plain and 51-610 mg/kg d.w. for this species obtained in Morag. Rasalanavhoa et al. (2020) [27] determined only 20-130 mg/kg d.w. of this mineral in Africa. Much higher Fe contents in B. badius from the province of Łódź were found by Karmańska \& Wędzisz (2010) [42]: 91.2-65.3 mg kg d.w. and Liu et al. (2016) [30] in China: 221-358 mg/kg d.w.

Similar values for $\mathrm{Zn}$ in C. cibarius from Poland were recorded by Brzezicha-Cirocka (2016) [34] (69-100 mg/kg d.w.), as well as Falandysz et al. (2017) [36] (87-100 mg/kg d.w.) and Kolundžić et al. (2017) [29] (94 mg/kg d.w.) in mushrooms from Serbia. However, Yildiz et al. (2019) [28] determined only $49.4 \mathrm{mg} / \mathrm{kg} \mathrm{d.w.} \mathrm{of} \mathrm{this} \mathrm{mineral,} \mathrm{and} \mathrm{Ouzouni} \mathrm{et} \mathrm{al.} \mathrm{(2007)} \mathrm{[17]} \mathrm{noted} 54.1 \mathrm{mg} / \mathrm{kg} \mathrm{d.w}$. Adamiak et al. (2013) [52] found Zn content in B. badius at the level of $126 \mathrm{mg} / \mathrm{kg}$ d.w., while Mleczek et al. (2016) [43] determined quantities in the range of $72-88 \mathrm{mg} / \mathrm{kg}$ d.w. in uncontaminated areas and 86-109 mg/kg d.w. in samples from contaminated areas. Giannaccini et al. (2012) [55] and Kojta \& Falandysz (2016) [33] obtained Zn content exceeding $120 \mathrm{mg} / \mathrm{kg}$ d.w., which is consistent with the data obtained as part of this study. Research carried out by Pająk (2016) [53] in the Świerklaniec Forest District, located near a metallurgical plant (Huta Zinc "Miasteczko Śląskie" [HCMŚ]), recorded a Zn level in B. badius at 142-305 mg/kg d.w. Similar contents of Zn were obtained by Brzezicha-Cirocka et al. (2016) [34] for B. edulis from Morag: $160 \mathrm{mg} / \mathrm{kg}$ d.w. (71-220 mg/kg d.w.). These authors determined higher values for mushrooms from Tarnobrzeska Plain: $210 \mathrm{mg} / \mathrm{kg}$ d.w. (130-320 mg/kg d.w). In Africa and China, a lower content of this element was determined: $53.6-107 \mathrm{mg} \mathrm{kg} \mathrm{d.w.} \mathrm{and} \mathrm{76-88} \mathrm{mg/kg} \mathrm{d.w.,}$ 
respectively [27,30]. Further, Karmańska \& Wędzisz (2010) [42] observed only 44.6-50.3 mg kg d.w. in B. edulis from the province of Łódź.

A comparable Mg content in C. cibarius was determined by Ayaz et al. (2011) [54] at the level of $815 \mathrm{mg} / \mathrm{kg}$ d.w. and Ouzouni et al. (2007) [17]: $866 \mathrm{mg} / \mathrm{kg}$ d.w. Larger amounts were observed by Brzezicha-Cirocka et al. (2016) [34]: 980-1400 mg/kg d.w. and Kolundžić et al. (2016) [29] 1426 mg/kg d.w. A significantly lower Mg content in C. cibarius was determined by Yildiz et al. (2019) [28] in mushrooms from Turkey: $106 \mathrm{mg} / \mathrm{kg}$ d.w. Higher Mg contents in B. badius were obtained by Kojta \& Falandysz (2016) [33], who studied fungi from Kẹtrzyn ( $811.5 \mathrm{mg} / \mathrm{kg}$ d.w.) Comparable values were determined in B. badius obtained in Augustów (531.5 mg/kg d.w.) [33]. Mleczek et al. (2016) [43] observed only $82-111 \mathrm{mg} / \mathrm{kg}$ d.w. of this mineral in this species collected from unpolluted sandy soil in the Wielkopolska region. They also obtained values of 503-611 $\mathrm{mg} \mathrm{kg} \mathrm{d.w.} \mathrm{from} \mathrm{contaminated} \mathrm{areas.}$ Similar contents of Mg in B. edulis were obtained by Liu et al. (2016) [30] in mushrooms from China (574-708 mg/kg d.w.) and Rasalanavho et al. (2020) [27] in fungi from Africa: $540-860 \mathrm{mg} / \mathrm{kg}$ d.w. Brzezicha-Cirocka et al. (2016) [34] received higher Mg contents in B. edulis collected in Tarnobrzeska Plain and Morag (850-910 mg/kg d.w.) The lowest values were determined by Karmańska \& Wędzisz (2010) [42] who studied mushrooms from the province of Łódź (306-324.9 mg/kg d.w.).

Generally, higher levels of $\mathrm{Cu}(670-1500 \mathrm{mg} / \mathrm{kg}$ d.w.) were obtained by Brzezicha-Cirocka et al. (2016) [34], Yildiz et al. (2019) [28] (673 mg/kg d.w.) and Kolundžić et al. (2017) [29] (92-892 mg/kg d.w.) Karmańska \& Wẹdzisz (2010) [42] determined 154-167 mg/kg d.w. of Ca in C. cibarius from the provine of Łódź. In B. badius, there was determined a lower Ca content determined than that provided by Kojta \& Falandysz (2016) [33] (197.5 mg/kg d.w.). Mleczek et al. (2016) [43] obtained the content of this mineral at the level of $24-33 \mathrm{mg} / \mathrm{kg}$ d.w. in B. badius collected from Polish uncontaminated acidic sandy soil and as much as $2322-2706 \mathrm{mg} / \mathrm{kg}$ d.w. from areas where alkaline flotation tailings from $\mathrm{Cu}$ production were stored. Karmańska \& Wẹdzisz (2010) [42] determined 75.7-152 mg/kg d.m. of calcium in B. badius from the province of Łódź. Ca contents in B. edulis were lower than those obtained by other researchers: $110-300 \mathrm{mg} / \mathrm{kg}$ d.w. and $160-900 \mathrm{mg} / \mathrm{kg}$ d.w. [34], 384-863 mg/kg d.w. [30], and $155.5-157.8 \mathrm{mg} / \mathrm{kg}$ d.w. [42]. The most similar values were observed in Africa (26.47-206.28 mg/kg d.w.) [27].

Obtained Na contents in C. cibarius are lower than those given by Brzezicha-Cirocka et al. (2016) [34] who received 140-360 mg/kg of this mineral. Kolundžić et al. (2017) [29], in mushrooms originating from Serbia, determined $2431 \mathrm{mg} / \mathrm{kg}$ d.w. of $\mathrm{Na}$, while Ayaz et al. (2011) [54] recorded $550 \mathrm{mg} / \mathrm{kg}$ d.w. The sodium content in the B. badius is comparable to that obtained by Kojta \& Falandysz (2016) [33] in Kętrzyn: $519 \mathrm{mg} / \mathrm{kg}$ d.w. The amount of Na in mushrooms studied by those authors in Augustów was determined at the level of $867 \mathrm{mg} / \mathrm{kg}$ d.w. Whereas Mleczek et al. (2016) [43] received values of $226-273 \mathrm{mg} / \mathrm{kg}$ d.w. in the B. badius obtained from Polish uncontaminated acidic sandy soil and $121-148 \mathrm{mg} / \mathrm{kg}$ d.m. in fungi from the contaminated area. The Na results obtained for B. edulis were within the range specified by Liu et al. (2016) [30] (617-1184 mg/kg d.w.), Rasalanavho et al. (2020) [27] (300-1050 mg/kg d.w.) and Brzezicha-Cirocka et al. (2016) [34], who studied mushrooms from Morag (57-1400 mg/kg d.w.). For B. edulis from Tarnobrzeska Plain, where the steel mill Huta Stalowa Wola is located, these authors presented lower values: $18-560 \mathrm{mg} / \mathrm{kg}$ d.w.

Similar contents of K in C. cibarius were found by Brzezicha-Cirocka et al. (2016) [34] $(42,000-59,000 \mathrm{mg} / \mathrm{kg}$ d.w.), while much smaller amounts were determined by Kolundžić et al. (2017) [29] (18,168 mg/kg d.w.) Ayaz et al. (2011) [54] determined the values for K at 32,500 mg/kg d.w. In B. badius, similar K content was obtained by Kojta \& Falandysz (2016) [33] in Kętrzyn at $37,500 \mathrm{mg} / \mathrm{kg}$ d.w. Smaller amounts were observed by Mleczek et al. (2016) [43] (17,584-18,932 mg/kg d.w.) in mushrooms from the province of Wielkopolska. In $\mathrm{Cu}$ contaminated areas, the K content was determined at 1731-1968 mg/kg d.w. [43]. In the case of B. edulis, a similar range of values for $\mathrm{K}$ was obtained by Brzezicha-Cirocka et al. (2016) [34] (27,000-32,000 mg/kg d.w.). Lower contents were determined by Rasalanavho et al. (2020) [27] in Africa: 18,180-2709 mg/kg d.w. and Liu et al. (2016) [30] (15,744-25,486 mg/kg d.w.) in China. 
The results obtained in this study, regarding eight selected minerals contained in Boletus edulis, Boletus badius and Cantharellus cibarius from the Warmia and Mazury region do not differ much from the results presented by other authors [27-34]. However, undoubtedly, chemical composition and properties of the growing substrate, as well as the contamination of the environment determine element composition in mushrooms. The experiment confirmed the occurrence of significant differences in content of studies micro- and macroelements depending on the species of fungi. Also, the region of collecting mushrooms had an impact on the content of some minerals as there were observed differences in the values for mushrooms growing in different parts of the world (South Africa, China, Turkey, Serbia).

To understand the role of soil geochemistry and soil pollution in accumulation of minerals in mushrooms fruiting bodies several studies have been conducted in Europe [56-58]. A few recent ones have shown that edible mushrooms growing in unpolluted areas can accumulate $\mathrm{Cd}$ and $\mathrm{Hg}$ at much higher levels as in soil substrate, while some species hyper accumulate $\mathrm{As}, \mathrm{Cd}, \mathrm{Hg}$, and $\mathrm{Pb}$ in the mining and geo-anomalous areas [22,59-62]. Research conducted by Pająk (2016) [53], who analyzed fungi collected from the Świerklaniec Forest District, located near a metallurgical plant, which is (Huta Cynku “Miasteczko Ślaskie" (HCMŚ)) confirmed the high accumulation of metals, including Zn mushrooms growing in highly polluted areas, and thus the possibility of using it as a bioindicator of the degree of contamination of the natural environment with heavy metals. Mleczek et al. (2016) [43] showed the effect of substrate purity on the accumulation of individual minerals by mushroom fruiting bodies. The results revealed the existence of relationships between the content of elements and low-molecular-weight organic acids. The considerably higher content of the minerals in mushrooms growing on flotation tailings than in soil was related with higher acid contents.

\section{Conclusions}

Assuming a 100\% bioavailability (in fact significantly lower as determined by many factors) of the studied minerals consumed with the analyzed mushrooms, the current study showed that these raw materials cover a significant percentage of the daily demand for many of the micro- and macroelements tested. This applies mainly to $\mathrm{Cu}, \mathrm{Zn}$, and $\mathrm{K}$, although none of the species is a good source of Ca and Na. Among the mushrooms studied, Cantharellus cibarius is the best source of most minerals, including $\mathrm{Cu}, \mathrm{Fe}, \mathrm{Mg}, \mathrm{Ca}$, and $\mathrm{K}$, although this requires further research to confirm the persistence of the observed trend.

The presence of minerals in human nutrition is very important. These elements are supplied to the body with food in the right proportions and determine the effectiveness of many life processes. The presence of a wide range of micro- and macroelements in edible mushrooms has prompted researchers to conduct numerous studies of the nutritional value of these raw materials. Moreover, the specificity of mushrooms and their bioindication abilities may constitute important criteria for determining their health quality and the degree of environmental pollution in their local area. The consumption of wild edible mushrooms is increasing worldwide. The knowledge and documentation of baseline mineral composition of wild growing mushrooms is essential to maintain nutritional needs, especially for many people who are vegetarian or maintain a vegan diet.

Author Contributions: M.G., participation in chemical analyses, interpretation and presentation and discussion of research results, statistical analysis; R.P.-F., participation in preparation of discussion of results, collection of references, corresponding author. M.G. and R.P.-F. contributed equally to this paper. All authors have read and agreed to the published version of the manuscript.

Funding: Project financially supported by Minister of Science and Higher Education in the range of the program entitled "Regional Initiative of Excellence" for the years 2019-2022, Project No. 010/RID/2018/19, amount of funding 12.000.000 PLN.

Conflicts of Interest: The authors declare that they have no known competing financial interests or personal relationships that could have appeared to influence the work reported in this paper. 


\section{References}

1. Statistical Yearbook of Forestry; Statistics Poland: Warsaw, Poland, 2019; ISSN 2657-3199. (In Polish)

2. Regional Operational Program of Warmińsko-Mazurskie Voivodeship for 2014-2020; Editors of the Regional Operational Program Promotion Team: Olsztyn, Poland, 2020. (In Polish)

3. Bernaś, E.; Jaworska, G.; Lisiewska, Z. Edible mushrooms as a source of valuable nutritive constituents. Acta Sci. Pol. Technol. Aliment. 2006, 5, 5-20.

4. Jaworska, G.; Bernaś, E. The effect of preliminary processing and period of storage on the quality of frozen Boletus edulis (Bull: Fr.) mushrooms. Food Chem. 2009, 113, 936-943. [CrossRef]

5. Dimitrijević, M.D.; Milić, S.M.; Alagić, S.Č.; Radojević, A.A. Revalorizacija platinske grupe metala (PGM) iz istrošenih autokatalizatora-Deo II-autokatalizatori-struktura i princip rada. Rec. Sustain. Dev. 2015, 8, 1-11.

6. Choma, A.; Nowak, K.; Komaniecka, I.; Waśko, A.; Pleszczyńska, M.; Siwulski, M.; Wiater, A. Chemical characterization of alkali-soluble polysaccharides isolated from a Boletus edulis (Bull.) fruiting body and their potential for heavy metal biosorption. Food Chem. 2018, 266, 329-334. [CrossRef] [PubMed]

7. Zhang, X.Y.; Lin, C.Y.; Zhu, J. Research progress in pharmacological activities of Boletus Edulis polysaccharides. J. Anhui Agric. Sci. 2015, 43, 4-5.

8. Wrzosek, M.; Sierota, Z. Mushrooms We Don't Know; State Forests Information Center: Warszawa, Poland, 2012; ISBN 978-83-6163-387-7. (In Polish)

9. Wang, X.; Zhang, J.; Li, T.; Wang, Y.; Liu, H. Content and Bioaccumulation of Nine Mineral Elements in Ten Mushroom Species of the Genus Boletus. J. Anal. Methods Chem. 2015, 1, 1-7.

10. Cohen, N.; Cohen, J.; Asatiani, M.D.; Varshney, V.K.; Yu, H.T.; Yang, Y.C.; Li, Y.H.; Mau, J.L.; Wasser, S.P. Chemical composition and nutritional and medicinal value of fruit bodies and submerged cultured mycelia of culinary-medicinal higher Basidiomycetes mushrooms. Int. J. Med. Mushrooms 2014, 16, 273-291. [CrossRef]

11. Prasad, S.; Rathore, H.; Sharma, S.; Yadav, A.S. Medicinal mushrooms as a source of novel functional food. Int. J. Food Sci. Nutr. Diet. 2015, 4, 221-225.

12. Muszynska, B.; Kała, K.; Rojowski, J.; Grzywacz, A.; Opoka, W. Composition and biological properties of Agaricus bisporus fruit-ing bodies-A review. Polish J. Food Nutr. Sci. 2017, 67, 173-181. [CrossRef]

13. Gebrelibanos, M.; Megersa, N.; Taddesse, A.M. Levels of essential and non-essential metals in edible mushrooms cultivated in Haramaya, Ethiopia. Int. J. Food Contam. 2016, 3, 2-12. [CrossRef]

14. Barros, L.; Cruz, T.; Baptista, P.; Estevinho, L.M.; Ferreira, I.C.F.R. Wild and commercial mushrooms as source of nutrients and nutraceuticals. Food Chem. Toxicol. 2008, 46, 2742-2747. [CrossRef] [PubMed]

15. Reis, F.S.; Martins, A.; Vasconcelos, M.H.; Morales, P.; Ferreira, I.C.F.R. Functional foods based on ectracts ora compounds derived from mushrooms. Trends Food Sci. Technol. 2017, 66, 48-62. [CrossRef]

16. Tang, C.; Hoo, P.C.X.; Tan, I.T.-H.; Pusparajah, P.; Khan, T.M.; Lee, I.H.; Gob, B.H.; Chan, K.G. Golden needle mushroom: A culinary medicine with evidenced-based biological activities and health promoting properties. Front. Pharmacol. 2016, 7, 474. [CrossRef] [PubMed]

17. Ouzouni, P.K.; Veltsistas, P.G.; Paleologos, E.K.; Riganakos, K.A. Determination of metal content in wild edible mushroom species from regions of Greece. J. Food Compos. Anal. 2007, 20, 480-486. [CrossRef]

18. Valverde, M.E.; Hernández-Pérez, T.; Paredes-López, O. Edible mushrooms: Improving human health and promoting quality life. Int. J. Microbiol. 2015, 2015, 1-14. [CrossRef] [PubMed]

19. Kalač, P. Edible Mushrooms: Chemical Composition and Nutritional Value; Elsevier: Amsterdam, The Netherlands, 2016.

20. Kalač, P. Chemical composition and nutritional value of European species of wild growing mushrooms: A review. Food Chem. 2009, 113, 9-16. [CrossRef]

21. Gałgowska, M.; Pietrzak-Fiećko, R. Pesticide contaminants in selected species of edible wild mushrooms from the north-eastern part of Poland. J. Environ. Sci. Health Part B 2017, 52, 214-217. [CrossRef]

22. Árvay, J.; Tomáš, J.; Hauptvogl, M.; Kopernická, M.; Kováčik, A.; Bajčan, D.; Massányi, P. Contamination of wild-grown edible mushrooms by heavy metals in a former mercury-mining area. J. Environ. Sci. Health Part B 2014, 49, 815-827. [CrossRef]

23. Niedzielski, P.; Mleczek, M.; Siwulski, M.; Gasecka, M.; Kozak, L.; Rissmann, I.; Mikołajczak, P. Efficacy of supplementation of selected medicinal mushrooms with inorganic selenium salts. J. Environ. Sci. Health Part B 2014, 49, 929-937. [CrossRef] 
24. Širić, I.; Humar, M.; Kasap, A.; Kos, I.; Mioč, B.; Pohleven, F. Heavy metal bioaccumulation by wild edible saprophytic and ecto-mycorrhizal mushrooms. Environ. Sci. Pollut. Res. 2016, 23, 18239-18252. [CrossRef]

25. Rzymski, P.; Klimaszyk, P. Is the yellow knight mushroom edible or not? A systematic review and critical viewpoints on the toxicity of Tricholoma equestre. Compr. Rev. Food Sci. Food Saf. 2018, 17, 1309-1324. [CrossRef]

26. Mleczek, M.; Siwulski, M.; Mikołajczak, P.; Gasecka, M.; Rissmann, I.; Goliński, P.; Sobieralski, K. Differences in $\mathrm{Cu}$ content in selected mushroom species growing in the same unpolluted areas in Poland. J. Environ. Sci. Health B 2015, 50, 659-666. [PubMed]

27. Rasalanavhoa, M.; Moodley, R.; Jonnalagadda, S.B. Elemental bioaccumulation and nutritional value of five species of wild growing mushrooms from South Africa. Food Chem. 2020, 319, 126596. [CrossRef] [PubMed]

28. Yildiz, S.; Gürgen, A.; Çevik, U. Accumulation of metals in some wild and cultivated mushroom ppecies. Sigma J. Eng. Nat. Sci. 2019, 37, 1371-1380.

29. Kolundžić, M.; Stanojković, T.; Radović, J.; Tačić, A.; Dodevska, M.; Milenković, M.; Sisto, F.; Masia, C.; Farronato, G.; Nikolić, V.; et al. Cytotoxic and Antimicrobial Activities of Cantharellus cibarius Fr. (Cantarellaceae). J. Med. Food 2017, 20, 790-796. [CrossRef]

30. Liu, Y.; Chen, D.; You, Y.; Zeng, S.; Li, Y.; Tang, Q.; Han, G.; Liu, A.; Feng, C.; Li, C.; et al. Nutritional composition of boletus mushrooms from Southwest China and their antihyperglycemic and antioxidant activities. Food Chem. 2016, 211, 83-91. [CrossRef]

31. Yin, L.L.; Shi, G.Q.; Tian, Q.; Shen, T.; Ji, Y.Q.; Zeng, G. Determination of the metals by ICP-MS in wild mushrooms from Yunnan, China. J. Food Sci. 2012, 77, 151-155. [CrossRef]

32. Georgescu, A.A.; Danet, A.F.; Radulescu, C.; Stihi, C.; Dulama, I.D.; Buruleanu, C.L. Nutritional and Food Safety Aspects Related to the Consumption of Edible Mushrooms from Dambovita County in Correlation with their Levels of Some Essential and Non-essential Metals. Rev. Chim. 2017, 68, 2402-2406. [CrossRef]

33. Kojta, A.K.; Falandysz, J. Metallic elements (Ca, Hg, Fe, K, Mg, Mn, Na, Zn) in the fruiting bodies of Boletus badius. Food Chem. 2016, 200, 206-214. [CrossRef]

34. Brzezicha-Cirocka, J.; Mędyk, M.; Falandysz, J.; Szefer, P. Bio- and toxic elements in edible wild mushrooms from two regions of potentially different environmental conditions in eastern Poland. Environ. Sci. Pollut. Res. 2016, 23, 21517-21522. [CrossRef]

35. Falandysz, J.; Borovička, J. Macro and trace mineral constituents and radionuclides in mushrooms: Health benefits and risks. Appl. Microbiol. Biotechnol. 2013, 97, 477-501. [CrossRef] [PubMed]

36. Falandysz, J.; Chudzińska, M.; Barałkiewicz, D.; Drewnowska, M.; Hanć, A. Toxic elements and bio-metals in Cantharellus mushrooms from Poland and China. Environ. Sci. Pollut. Res. 2017, 24, 11472-11482. [CrossRef] [PubMed]

37. Mleczek, M.; Siwulski, M.; Kaczmarek, Z.; Rissmann, I.; Sobieralski, K.; Goliński, P. Concentration of selected trace element in Xerocomus badius mushroom bodies- a health risk for humans? Acta Sci. Pol. Technol. Aliment. 2013, 12, 331-343. [PubMed]

38. Mleczek, M.; Budka, A.; Siwulski, M.; Mleczek, P.; Gąsecka, M.; Jasińska, A.; Kalač, P.; Sobieralski, K.; Niedzielski, P.; Proch, J.; et al. Investigation of differentiation of metal contents of Agaricus bisporus, Lentinula edodes and Pleurotus ostreatus sold commercially in Poland between 2009 and 2017. J. Food Compos. Anal. 2020, 90, 103488. [CrossRef]

39. Siwulski, M.; Sobieralski, K.; Sas-Golak, I. Nutritive and health-promoting value of mushrooms. Żywn. Nauka Technol. Jakość 2014, 1, 16-28.

40. Siwulski, M.; Rzymski, P.; Budka, A.; Kalač, P.; Budzyńska, S.; Dawidowicz, L.; Hajduk, E.; Kozak, L.; Budzula, J.; Sobieralski, K.; et al. The effect of different substrates on the growth of six cultivated mushroom species and composition of macro and trace elements in their fruiting bodies. Eur. Food Res. Technol. 2019, 245, 419-431. [CrossRef]

41. Rzymski, P.; Mleczek, M.; Siwulski, M.; Jasińska, A.; Budka, A.; Niedzielski, P.; Kalač, P.; Gąsecka, M.; Budzyńska, S. Multielemental analysis of fruit bodies of three cultivated commercial Agaricus species. J. Food Compos. Anal. 2017, 59, 170-178. [CrossRef]

42. Karmańska, A.; Wędzisz, A. Content of selected macro- and microelements in various species of large fruiting body mushrooms collected in the province of Łódź. Bromat. Chem. Toksykol. 2010, 43, 124-129. (In Polish) 
43. Mleczek, M.; Magdziak, Z.; Gąsecka, M.; Niedzielski, P.; Kalač, P.; Siwulski, M.; Rzymski, P.; Zalicka, S.; Sobieralski, K. Content of selected elements and low-molecular-weight organic acids in fruiting bodies of edible mushroom Boletus badius (Fr.) Fr. from unpolluted and polluted areas. Environ. Sci. Pollut. Res. 2016, 23, 20609-20618. [CrossRef]

44. Florczak, J.; Chudy, J.; Barasińska, M.; Karwowski, B. Contents of selected nutrients in wild-grown Hirneola auricula judae, Pleurotus ostreatus and Flammulina velutipes mushrooms. Bromat. Chem. Toksykol. 2014, 47, 876-882.

45. Falandysz, J.; Drewnowska, M.; Jarzyńska, G.; Zhang, D.; Zhang, Y.; Wang, J. Mineral constituents in common chanterelles and soils collected from a high mountain and lowland sites in Poland. J. Mt. Sci. 2012, 9, 697-705. [CrossRef]

46. Kalač, P. Trace element contents in European species of wild growing edible mushrooms: A review for the period 2000-2009. Food Chem. 2010, 122, 2-15. [CrossRef]

47. PN-68/A-78508 Fresh Mushrooms and Mushroom Products-Collection and Sample Preparation; Polish Committee for Standardization: Warszawa, Poland, 1969.

48. Whiteside, P.; Miner, B. Pye Unicam Atomic Absorption Data Book; Pye Unicam LTD: Cambridge, UK, 1984.

49. Jarosz, M.; Rychlik, E.; Stoś, K.; Wierzejska, R.; Wojtasik, A.; Charzewska, J.; Mojska, H.; Szponar, L.; Sajór, I.; Kłosiewicz-Latoszek, L.; et al. Nutrition Standards for the Polish Population; Food and Nutrition Institute: Warszawa, Poland, 2017; ISBN 978-83-86060-89-4.

50. Mleczek, M.; Niedzielski, M.; Kalač, P.; Budka, A.; Siwulski, M.; Gąsecka, M.; Rzymski, P.; Magdziak, Z.; Sobieralski, K. Multielemental analysis of 20 mushroom species growing near a heavily trafficked road in Poland. Environ. Sci. Pollut. Res. 2016, 23, 16280-16295. [CrossRef] [PubMed]

51. Kuziemska, B.; Wysokiński, A.; Jaremko, D.; Pakuła, K.; Popek, M.; Kożuchowska, M. The content of copper, zinc, and nickel in the selected species of edible mushrooms. Environ. Prot. Nat. Res. 2019, 30, 7-10.

52. Adamiak, E.A.; Kalembasa, S.; Kuziemska, B. Contents of heavy metals in selected species of edible mushrooms. Acta Agrophysica 2013, 20, 7-16. (In Polish)

53. Pajak, M. The content of zinc, lead and cadmium in bay bolete (Xerocomus badius (FR.) E.) collected from a strongly polluted forest complex. Inż. Ekolog. 2016, 49, 221-226. (In Polish) [CrossRef]

54. Ayaz, F.A.; Torun, H.; Colak, A.; Sesli, E.; Millson, M.; Glew, R.H. Macro- and microelement contents of fruiting bodies of wild-edible mushrooms growing in the East Black Sea Region of Turkey. Food Nutr. Sci. 2011, 2, 53-59. [CrossRef]

55. Giannaccini, G.; Betti, L.; Palego, L.; Mascia, G.; Schmid, L.; Lanza, M.; Mela, A.; Fabbrini, L.; Biondi, L.; Lucacchini, A. The trace element content of top-soil and wild edible mushroom samples collected in Tuscany, Italy. Environ. Monit. Assess. 2012, 184, 7579-7585. [CrossRef] [PubMed]

56. Borovička, J.; Kotrba, P.; Gryndler, M.; Mihaljevič, M.; Řanda, Z.; Rohovec, J.; Cajthaml, T.; Stijve, T.; Dunn, C.E. Bioaccumulation of silver in ectomycorrhizal and saprobic macrofungi from pristine and polluted areas. Sci. Total Environ. 2010, 408, 2733-2744. [CrossRef] [PubMed]

57. Kojta, A.K.; Wang, Y.; Zhang, J.; Li, T.; Saba, M.; Falandysz, J. Mercury contamination of Fungi genus Xerocomus in the Yunnan Province in China and the region of Europe. J. Environ. Sci. Health Part A 2015, 50, 1342-1350. [CrossRef] [PubMed]

58. Kubrová, J.; Borovička, J. Do macrofungi accumulate uranium'. In 'Uranium-Past and Future Challenges', Proceedings of the 7th International Conference on Uranium Mining and Hydrogeology; Merlel, B.J., Arab, A., Eds.; Springer International Publishing: Cham, Switzerland, 2015; pp. 369-376.

59. Zhang, J.; Barałkiewicz, D.; Hanć, A.; Falandysz, J.; Wang, Y. Contents and health risk assessment of elements in three edible ectomycorrhizal fungi (Boletaceae) from polymetallic soils in Yunnan Province, SW China. Biol. Trace Elem. Res. 2020, 195, 250-259. [CrossRef] [PubMed]

60. Mleczek, M.; Siwulski, M.; Mikołajczak, P.; Gąsiecka, M.; Sobieralski, K.; Szymańczyk, M.; Goliński, P. Content of selected elements in Boletus badius fruiting bodies growing in extremely polluted wastes. J. Environ. Sci. Health Part A 2015, 50, 767-775. [CrossRef] [PubMed] 
61. Kojta, A.K.; Gucia, M.; Krasińska, G.; Saba, M.; Nnorom, I.C.; Falandysz, J. Mineral constituents of edible field parasol (Macrolepiota procera) mushrooms and the under lying substrate from upland regions of Poland: Bioconcentration potential, intake benefits, and toxicological risk'. Pol. J. Environ. Stud. 2016, 25, 2445-2460. [CrossRef]

62. Saba, M.; Falandysz, J.; Loganathan, B. Accumulation Pattern of Inorganic Elements in Scaly Tooth Mushroom (Sarcodon imbricatus) from Northern Poland. Chem. Biodivers. 2020, 17, e2000167. [CrossRef] [PubMed]

Sample Availability: Samples of the compounds are not available from the authors.

(C) 2020 by the authors. Licensee MDPI, Basel, Switzerland. This article is an open access article distributed under the terms and conditions of the Creative Commons Attribution (CC BY) license (http://creativecommons.org/licenses/by/4.0/). 